\title{
A Prison Librarian Looks at Writ-Writing
}

\author{
Herman C. Spector*
}

7 His ARTICle is NOT INTENDED to dispute contentions made in the 1 companion article by Mr. Larsen. Its purpose is merely to present a prison official's point of view regarding the problems of the jailhouse lawyer and operation of the prison library. We realize that some inmates feel they lave legitimate complaints wlich require a court's attention, and we are anxious that our men present valid cases for review. We understand fully the inmate's desire to exhaust all his legal remedies.

I

THE JAILHOUSE LAWYER

It is ironic that Mr. Larsen focuses his attention on writ-writers, for the vast majority of those inmates using the prison legal library are not writ-writers, but rather jailhouse lawyers. The distinction is that while writ-writers process their own cases, jailhouse lawyers work on others' cases. We feel that jailhouse lawyering presents two problems: first, we attribute much of the friction between inmates to the inability of one man to pay another his "fee," earned for the performance of legal services; second, some men, under the pretense of doing their own legal work, flood the prison administration, not to mention the courts, with spurious claims.

\section{A. Payment for Jailhouse Lawyer's Services}

Jailhouse lawyers do a thriving business in San Quentin. Despite their frequent claims, inmates do not do favors for other inmates without some remuneration. Therefore, when one inmate spends his time and effort doing legal researcli for another, it is with the clear understanding that he will be paid. Payment can take any of the following forms: commissary goods, such as candy, cigarettes and food; clothing; or a homosexual relationship. Not all "payments" are due at the prison. The "understanding" may require some pay-off when the debtor-inmate is paroled or discharged, or he may be expected to arrange for payment while visiting with his family.

Naturally, not all such agreements are honored. Breaches may occur when an inmate is paroled or discharged sooner than had been expected, or when he is transferred to another institution. When the agreement cannot be honored, fights imvolving several men may ensue. Upon several

'B.S., State Teacher's College, West Chester, Pa.; M.A., Columbia University, Teacher's College; B.S. in Library Science, Columbia University School of Library Service; Prison Librarian, San Quentin Prison. 
occasions, we have been compelled to isolate "clients" in solitary confinement to protect them from their "jailhouse lawyers." Alternatively, more promises are made, time periods are extended, and interest is charged. Few men escape the creditor's tenacious claws. There have been threats of blackmail, made possible because the "lawyer"-creditor knows all the facts of his debtor's case. Nor do the threats and violence occur only within the prison. Both may extend to family and friends of the inmate who is unable to pay.

The jailhouse lawyers seem to have a steady clientele despite the constantly changing prison population. Word somehow reaches the new inmate, or he may be approached directly with the assurance that the person presenting himself is an "ex" lawyer, or a "specialist" who has been successful in winning cases. We attempt to deal with the problem both by prohibiting one immate from doing legal work on another's case and by confiscating legal materials which an inmate is not authorized to possess. In this connection it should be noted, however, that our rules provide:

Inmates may receive or purchase a single copy of an opinion or decision in their own case and retain it in their own possession. Legal documents such as a return on an order to show cause which contain cumulative case summary information will be placed in the inmate's property and made available for reference under supervision. ${ }^{1}$

\section{B. The Jailhouse Lawyer as Vexatious Litigant}

The second problem presented by jailhouse lawyering concerns its use as a pretense for the presentation of spurious claims to the courts and to the prison administration. Some men use the legal process to wage a continual vendetta with the courts. Although only a few inmates fall within this classification, they are a determined lot.

Most of the men understand the rules governing use of the prison's legal library services. Quite a few, however, following their impulsive and overriding cynicism, make exhorbitant demands on the library, specifically on the librarian. They write frequent and annoying letters to the warden, the captain, and the lieutenant in charge. Many of these letters contain claims which are totally unwarranted. They cast aspersions on the integrity of the librarian and upon his desire to provide them with books which, though demanded, are not available. Prisoners become enmeshed in problems from which they cannot extricate themselves, and they blame the hbrarian. They fail to recognize their obligations and to respect the privileges granted to them. For example, they demand to come during hours not designated as open hbrary hours. They demand that no

\footnotetext{
1 Department of Corrections Administrative Manual, If 330.045 .
} 
one use the books they are presently using. Some want to come in several times a week, and some bring their friends and "assistants" to stay with them. In numerous personal confrontations regarding their grievances, inmates exacerbate the situation by compounding a legitimate claim with all sorts of unrelated factors.

This group of men writes to the clerks of the courts and to judges. They present petitions and write pernickety letters and writs which make untruthful and grossly exaggerated claims regarding interference with their petitions by personnel of the institution. They write interminably long and confusing letters to the warden and his staff, revealing their pervasive and piquant cynicisin concerning all law agencies and officers. All complaints are answered by making a detailed report to the warden. In some circumstances the Attorney General's office requests a report answering an inmate's claim.

Inmates may manifest their grievances in ways more disturbing than the mere filing of spurious claims. A few are organized and they try to use "muscle pressure" when they aggressively and defiantly come into the library. They inake threatening demands for the benefit of all who nnay be trying to use the library at that time. Sucli conduct can, and sometimes does, lead to rules violations. Some men try to abstain from their work assignments and thus involve their foreman or supervisor in the battle to get their legal work done. Frequently, this is done only to get out of the work detail. This is one reason why the hbrary operates seven days a week.

\section{II \\ OPERATION OF THE PRISON LIBRARY}

\section{A. The Problem}

Anyone concerned with the legitimacy of inmates' complaints about the adequacy of prison library facilities must be aware of the following facts: The size of the entire library, including the legal section, is 3,200 square feet, and there is seating capacity for only thirty-two men. We deal with an average inonthly prison population of 3,630 men. Most of the time about ninety per cent of the library space is occupied by inmates doing legal work. During an average nonth the nnmber of men domg legal research is 267 . This group uses the hibrary facilities approximately 649 times during an average month. In order that these men need not neglect their prison work duties to do legal research, the library is open seven days a week. At this time we liave no accurate estimate of the costs incurred in operating the prison library. It is worth mentioning, lowever, that of the eiglt inmates who work in the hibrary, one devotes all his time to the clerical details involved in our legal services. 
Our Department, in paragraph 330.041 of its official Administrative Manual, declares that a uniform list of law books and reference material be made available in each institution. This list includes a standard set of basic codes and references. ${ }^{2}$ It definitely stipulates that titles shall be himited to those listed, but it adds in paragraph 330.042 that "sufficient copies will be maintained to provide reasonable access." The State Library issued the hist. We agreed to accept it. The hist was pubhished in our inmate newspaper, the San Quentin News, and explanatory statements provided by the State Library were added. The State Library is under no obligation to furnish the Department of Corrections with the legal material requested by inmates. The excellent cooperation and assistance which they do render us is merely one of gracious administrative courtesy. The State Library has been helping us in this field, as in many other areas, for unany years. Their primary responsibility is, of course, to provide assistance to our Legislature. With the unbelievably large growth of our prison population, the inordinate number of men who are making requests for legal literature, and the impossibility of the State library meeting such excessive demands, it was found necessary to limit the State library's responsibility to provide us with such books. Because of the everincreasing deinands made upon its limited resources, the State library found it necessary to notify our Central Office that it is

unable to make any additions to the prison material that is currently being circulated to the Department of Corrections institutions. This specifically applies to the law books requested by various institutions.

The books are being returned, in some cases, with large sections missing. If this service is to be continued, and be meaningful, an effort must be made to protect the material.

This announcement followed assurances, contained in the Department of Corrections Administrative Manual, that "service of the State Law Library will be continued."

The library has only one full time librarian, although he is assisted

2 Paragraph 330.041 provides that there shall be established in each institution a standard set of basic codes and references which shall consist of and be limited to:

1. The California Penal Code

2. The California Welfare and Institutions Code

3. The California Health and Safety Code

4. The California Vehicle Code

5. The United States and California Constitutions

6. A recognized law dictionary (such as Black's)

7. Witkin's California Criminal Procedures (Bender Moss Co.)

8. Subscription to California Weekly Digest

9. California Rules of Court

10. Rules of United States Court of Appeals (Ninth Circuit)

11. Rules of United States Suprenie Court 
by a part time teacher. Together with our crowded facilities, this makes proper supervision of the library impossible. It is easy, when the "boss" is in another area, or answering the telephone, for an inmate to mutilate a law book, sometimes by cutting pages. Legal materials on habeas corpus are particularly liard to keep on the shelves. The library budget is small and we must provide both legal and nonlegal material. Because of their high cost, mutilation of law books disproportionately depletes the library's funds. This is particularly important since we try to maintain an adequate supply of books which circulate in the prison. Since law books generally may not be taken out of the library, their acquisition and replacement necessarily limits the number of books which the men may enjoy at their own leisure.

We do keep records showing which inmate used what books, and we can also maintain some control through our individual loan system. However, the books are used between eleven hundred and twelve liundred times each month. For us to take time to check the books this often would certainly "jam" the whole procedure and delay numerous authentic and legitimate uses which are made of these books by most of our men. Of course, each inmate is held personally accountable for damage or loss which we are able to trace to him. In determining liabihity the following procedure is used: First the librarian writes a violation report. This report is then submitted to a disciplinary committee whicl hears the case. If the inmate is found guilty, the hbrary assesses the purchase price of the book and the inmate must pay, if he has the funds. If he does not have sufficient funds, then a "freeze" is placed on his account, and whenever money comes into his account the charge is deducted.

Death row cases present very special problems for us. All men sentenced to death are automatically entitled to appeal their cases. It stands to reason, then, that from this unit we get a constant and ever increasing number of requests for materials. We give special consideration to requests from these men, and whenever possible we give them priority on use of available materials. Although most inmates cannot remove books from the hibrary, we are authorized to allow inmates on death row to use the books in their cells. When the material they desire is not immediately available at the prison or the State hbrary we renew our request from the latter every seven days.

In order to expedite the filing of legal documents by all inmates our institution makes available mimeographed copies of various petitions and forms, including affidavit of verification, proof of service by mail, motion to proceed in forma pauperis, and petition for writ of habeas corpus. We are, of course, anxious that our men present legitimate and valid cases for review. We trust that they follow impeccable integrity in their claims 
and that the facts and court opinions which they present have unquestionable authenticity, thereby making it easier for the courts to do their share.

\section{B. Suggestions for Reform}

Perhaps the state should appoint a special legal ombudsman to mamtain vigilance over the human rights of incarcerated felons and ask that they be afforded appropriate remeclies. Undoubtedly we do need to have more specific and detailed formulation of standards to achieve absolute legal justice. The responsibility of the librarian would be to help each inmate in his effort to correct possible errors in the judgment ordering his imprisonment. Although not legally trained himself, he might then be able to relieve the frustration of these inen who feel that alone they "can't fight city hall." Such a system, in addition to reheving pressure on the courts, would place the inmates in a better position to secure their rights than when they must rely on their own efforts. It would also help to promote a greater spirit of understanding and mutual assistance. The administrative staff, the hibrarian, and the inmates must find some ineans for the orderly exploration of their mutual problems. This suggestion would represent a minimal first step. Secondly, we must provide clearly stated uniform policies, procedures, and rules which would apply to these men as a group. What hittle we have done here is certainly not a cure-all. 